\title{
Deconstruction of the Sengkuni Figure in the Drama Sengkuni 2019 by Emha Ainun Nadjib
}

\author{
Fitriatunnisa* \\ Indonesian Language and Literature Education of \\ Graduate School \\ Universitas Negeri Yogyakarta \\ Yogyakarta, Indonesia \\ Fitriatunnisa0251.pasca2018@student.uny.ac.id
}

\author{
Suroso \\ Indonesian Language and Literature Education of \\ Graduate School \\ Universitas Negeri Yogyakarta \\ Yogyakarta, Indonesia \\ suroso@uny.ac.id
}

\begin{abstract}
The research aimed to describe the forms of thought of Sengkuni and the reversal of the binary opposition hierarchy using Jacques Derrida's deconstruction theory in the drama Sengkuni 2019 by Emha Ainun Nadjib. This research was descriptive qualitative. The data in this study were texts contained in the 2019 drama Sengkuni which outlines the form of thought and the reversal of the binary opposition hierarchy. The data source in this study was the 2019 drama Sengkuni. The data collection method was reading, notes, and interpretation techniques. This research was conducted by identifying, classifying, describing, and analyzing forms of thought and reversing the hierarchy of Sengkuni's binary opposition in the drama Sengkuni 2019 by Emha Ainun Nadjib using Jacques Derrida's Deconstruction theory. The results of this study proved the existence of the main character Sengkuni's hypocritical and antagonistic personality. However, after being analyzed by reversing the hierarchy of binary opposition to Sengkuni's character, there was a consistent and protagonist character contained in the 2019 drama Sengkuni text.
\end{abstract}

\section{Keywords-Deconstruction, Drama, Binary Opposition}

\section{INTRODUCTION}

Literary works that have been born at this time were developed as a historical document from the thought and even philosophy. This can be justified as literature is a form of historical reflection through thoughts that are expressed directly or through characters or events in the literary works. This is the reason why the author has a very important role in creating literary works.

The 2019 Sengkuni drama by Emha Ainun Nadjib took Sengkuni, the puppet character from Mahabharata's story, as the main character. In the development of Indonesian literature, it is common that wayang stories used as a source of inspiration for writing modern Indonesian literature in addition to those relating to other monumental facts such as historical events. Many situations and events in the puppet world often seen as symbols or circumstances and events in the real world. Puppet is not only a popular form of art but has become a part of life that society needs. [7]

Puppet and puppet world were always associated with the words of philosophy, religious myths, magic, mysticism, and so forth. If the understanding of each of these words is not understood, the expression will be chaotic. Therefore, the meaning of philosophy needs to be well understood. [10]
Linking puppets and philosophy is necessary to understand the meaning in this drama. Wayang is a work that has standard traditions and conventions. Also, it's used as a basis for the work thereafter. However, in the 2019 drama Sengkuni, the character of Sengkuni is depicted as a character who deviates and rebels from tradition and even has a distortion of essence.

This drama did not adopt the whole wayang story. Emha only took the character Sengkuni as the main character of the story and deconstructed the character. The researcher used Jacques Derrida's deconstruction theory to explore the meaning of this drama.

Jacques Derrida, a French philosopher born in Algeria, introduced Deconstruction. This theory criticizes the mode of meaning that is centralized and tends to be round as might be desired in the text or which is deliberately raised implicitly by the logical relationship of the text.

The power of the "unspeakable" text is underestimated logic as a secondary meaning which at times jeopardizes the building of the text or produces ambiguous paradoxes, which will undermine the reader. Just like drama that frequently used colloquial speech. [6]

With Derrida's deconstruction logic it is hoped that we can understand the phenomena in the text later. Derrida's deconstruction offers textuality that changes tradition and history. This is an attempt to enrich cultural understanding and phenomena, especially how Sengkuni figures are contemporary interpreted.

This research aimed to describe the dominant views depicted by the author released from the concept of thought, which become the basis of the story. Then, things that appear to be used by the author will be presented to destroy the story structure that has been structured. Thus, the meaning that emerges is the result that constantly presents from the meaning of the new signifiers that available. The meaning that will later be produced is not only text data that can be just enjoyed, but also the results of the interpretation process.

Barry [2] stated that the structure referred is the structure imposed by the way we perceive the world and organize our experiences, not the objective entities that already exist in the external world.The same thing expressed by Faruk [4] the dialogical nature of the literary work does not only express itself in the fact that the work is related to discourse that exists outside of itself. 
Deconstruction is not only a form of rearranging everything that has been established. Deconstruction is understood as an ethical dimension that seeks to open oneself to "the other". Derrida's reversal of ethics indirectly broke the nihilistic label given to Derrida's deconstruction.

Deconstruction was designed by Derrida as something within the text. Deconstruction does not work as a method or theory applied "from outside" the text but works parasitically from the material and source of the text being read. Deconstruction, as confirmed by Derrida [3] is always done from within the text.

"The movements of deconstruction do not destroy structures from the outside. They are not possible and effective, nor can they take accurate aim, except by inhabiting those structures. Inhabiting them in a certain way, because one always inhabits, and all the more when one does not suspect it. Operating necessarily from the inside, borrowing all the strategic and economic resources of subversion from the old structure, borrowing them structurally, that is to say without being able to isolate their elements and atoms, the enterprise of deconstruction always in a certain way falls prey to its own work".

Poststructuralism has a distinctive character. It is placing the meaning of the work by what the text does, not by what the text means. So that there is a shift from the aesthetic of production to the aesthetic of consumption, the recipient becomes the creator.

A text always has multiple faces. When we think about the meaning and draw conclusions from that meaning, at the same time the text carries another different meaning from what we have taken. That different meaning is often unpredictable as it may be a secondary meaning that is not desired by the author. [1]

In reading a literary text, the reader will always draw conclusions related to the storyline or characterizations of each character presented. The author clearly depicts the character in accordance with the storyline. For instance, the character A has a grumpy character, so each dominant text in the storyline will display the character of the A as an angry person, this dominant text is what Derrida calls a binary dichotomy (dominant text). Drama literary works often do not really show the dominant text when describing the character of a character, herein lies the creativity of a writer in shaping the character's character who will run the storyline. The character A who is known as a bad-tempered person can be deconstructed by presenting binary opposition (opposite words) from the character of a grumpy character to be patient. Afterward, a secondary text (aporia) will be found showing the opposite character of the dominant character through repeated reading of the text. Therefore, it can be ascertained that the A actually does not really have the temper temperament like the understanding at the beginning, which presents the dominant texts as a standard meaning of the temperament character of $\mathrm{A}$ as an angry person.
This is in line with the Marcelus' statement [8] Derrida discusses big ideas that are abstract, but the way Derrida reads the text is just the opposite as it is done in great detail down to the small things.

For the deconstructionist, first of all, they must expose contradictions or paradoxes which are showing that the feelings expressed openly in his writings may be contradicting the feelings expressed. Next, referring to fractures, gaps, cracks, and discontinuities is the way to imply that the text lacks coherence and consistency of purpose. Then, the linguistic peculiarities or those which can weaken the fixed meaning. [2]

\section{METHODOLOGY}

This research discussed deconstruction analysis of the 2019 drama Sengkuni script by Emha Ainun Nadjib. This research was classified as a descriptive qualitative research. In capturing the data, the researcher described the dissection of the text of the Sengkuni 2019 manuscript by Emha Ainun Nadjib using Jacques Derrida's deconstruction theory.

Reading the text is done not solely aimed at writing, but to all related cultural statements. This should be done because statements or dialogues in the text itself already contain values, prerequisites, ideologies, truths and certain goals. Therefore, attitudes, behavior, political situation, governance, social, cultural and so on are the parts of a text that can be read like a book.

With the principle of qualitative descriptive research methods mentioned above, this research design used includes collecting, managing, reducing, analyzing and presenting data objectively or in accordance with the reality available to obtain data.

\section{RESULT AND DISCUSSION}

The 2019 Sengkuni drama was first staged at the Taman Budaya Yogyakarta on January 12-13th, 2019. Then was performed again at Balai Budaya, the Balai Pemuda Surabaya complex on March 7-8th, 2019. This drama took the story of Sengkuni in the Mahabharata epic.

\subsection{Sengkuni at the Mahabharata Epic}

The Sengkuni figure appears in the Adiwarna and Sabhaparwa stories, which are part of the Mahabharata epic.

Adiparwa - Contains various Hinduism stories, such as the story of Mandaragiri turning, the story of Begawan Dhomnya who tested his three students, the story of the Pandava and Kaurava ancestors, the story of the birth of Resi Byasa, the story of the childhood Pandavas and the Kauravas, the story of the death of the Giant Hidimba at the hands of Bhimasena, and the story of Arjuna getting Dropadi.

Basically, this section contains a summary of the whole Mahabharata story, stories about the background of the story, the ancestors of the Bharata family, to the youth of the Kauravas and the Pandavas. The story of Bharata's big 
family begins with a conversation between Bagawan Ugrasrava who came to Bagawan Sonaka in the Nemisa forest

Sabhaparwa - the story of a meeting between Pandavas and Kauravas in a hall to play gambling, on the plans of Duryodhan. Because of Sengkuni's cunning effort, the game was won twice by the Kauravas. Hence, according to the agreement, the Pandavas had to go for seclusion to the forest for 12 years and went through a disguise for 1 year after that. [10]

Sengkuni was one of the puppet characters that have a strong character among the other. He is associated with cunning nature, full of deception, provocateurs, and ucukucuk expert. He was responsible for the raged of the Bharatayuda war, civil war and bloodshed in Padang Kurusetra between Pandava knights and Kaurava warriors. [9]

In brief, the play can be described as follows:

There is no other figure in the world of wayang that can match Sengkuni's fame in terms of cunning and rottenness. In the figures of Burisrawa, Durna, Dursasana, Jayadrata, or Duryudana, it is possible to find the good side, vaguely. But it will be difficult to find in the figure of Sengkuni. So it cannot be denied, the figure of Sengkuni, also known as Haryo Suman or Trigantalpati, has been named as a genuine antagonist. [9]

Sengkuni has always done any means to achieve the goal. That led Sengkuni to get the vice-regent position of Astina from the hands of Gandamana. At that time, the control of the government of Astina was in the hands of Pandu Dewanata. In the story "Gandamana Luweng"A, Sengkuni devised a deception and slander to overthrow Patih Gandamana from his position. Sengkuni set up a trap pit to eliminate Gandamana, but the effort was unsuccessful. [9]

Sengkuni and his family were imprisoned by the King of Hastinapur -Dretarastra- who also his brother in law. This happened initially when Sengkuni had good intentions to marry his sister Gandari with Pandu, heir to Hastinapur's throne with comprehensive consideration. But in fact, Gandari actually married Dretarastra, Pandu elder brother with the consent of his parents. Sengkuni did not agree but remained loyal to escort his sister (Gandari). To avoid the calculation of primbon, so that Gandari and Dretarastra match, Gandari was married to a goat. After being married off, the goat was slaughtered, so the calculation changed as Gandari was a widow when he married. This caused Dretarastra's anger.

While in prison, they were only given a grain of rice to eat every day. Of course, this was not enough to survive. Based on the mutual agreement, someone must live to regenerate the family. There was no other way during his imprisonment. Sengkuni had to ate his mother, father, and siblings for years.

\subsection{Deconstruction in 2019 Sengkuni}

\section{- Sengkuni's behavior is not an evil but a form of suffering}

In the 2019 Sengkuni drama script the dominant character of Sengkuni is a description of Sengkuni's character in the form of dialogue involving Sengkuni's characters directly or through dialogue between other characters.

Unlike the Mahabharata epic, in the 2019 Sengkuni text, Sengkuni had not only four relatives but 98 relatives. The same story with the epic Mahabharata was when Sengkuni and his entire family (except Gandari) was imprisoned by the King of Hastinapur -Dretarastra- who also his brother in law. This happened initially when Sengkuni who had good intentions to marry his sister Gandari with Pandu, heir to Hastinapur's throne with comprehensive consideration. But in fact, Gandari actually married Dretarastra, Pandu elder brother with the consent of his parents. Sengkuni did not agree but remained loyal to escort his sister (Gandari). To avoid the calculation of primbon, so that Gandari and Dretarastra match, Gandari was married to a goat. After being married off, the goat was slaughtered, so the calculation changed as Gandari was a widow when he married. This caused Dretarastra's anger.

While in prison, they were only given a grain of rice to eat every day. Of course, this was not enough to survive. Based on the mutual agreement, someone must live to regenerate the family. There was no other way during his imprisonment. Sengkuni had to ate his mother, father, and siblings for years as in the following quote:

"Ini tentang 101 orang sekeluarga yang dikurung dalam penjara dan hanya mendapatkan satu butir nasi untuk makan sehari. Mustahil bertahan hidup dengan sebutir nasi untuk makan sehari. Maka siapa saja di antara saudara-saudara saya yang menuju sekarat, termasuk Romo dan Ibu saya -begitu mati, langsung saya mutilasi untuk stok makanan saya. Maaf, ini bukan kejam. Ini darurat perjuangan. Ini keputusan Romo saya dan yang disepakati oleh kami semua sekeluarga. Ini soal kesetiaan. Ini tentang betapa utamanya martabat keluarga."

In this part of the story, the depiction of Sengkuni's suffering appeared. This was confirmed again in the quotation of Sengkuni's dialogue with his brothers Sengkanu, Sungkono and Sangkani as follows:

\section{NARATOR:}

Kalian menderita hanya sesaat, kemudian mati. Sedangkan saya harus memakan kalian. Memakan kalian, saudara saya sendiri. Sanak-kadangku sendiri. Sedarah. Kita keluar dari rahim ibu yang sama. Ibu yang sangat kita cintai. Emang enak makan saudara sendiri? Apalagi Ibu dan Bapak sendiri. Apakah ada penderitaan yang lebih dari itu? 
SUNGKONO

Keputusan Bopo Subolo sudah bulat

\section{SANGKANI}

Kita sekeluarga sudah total bertekad

\section{NARATOR}

Derita tiada tara, terulur sepanjang usia, melampaui cakrawala kepedihan tak hanya sangat mendalam, bahkan tak ada lubuknya.

\section{SANGKANI}

Saya sangat bisa merasakannya.

The mental burden that he must bear throughout his life is suffering. As bad as human behavior, he will not have the heart to eat the flesh of his brother, father, and mother himself. Nothing is sadder when we have to hurt the people we care about. This was not a form of evil but a form of long-suffering. Even under these conditions, Sengkuni and his family did not get help, defense or even care. As the following quote:

\section{SANGKANI}

Andaikan saya berdaya, sekarang pun saya siap melabrak mereka yang memenjarakan kita

\section{SENGKANU}

Tidak ada yang membela kita

\section{SUNGKONO}

Tidak ada yang menolong kita

\section{SANGKANI}

Tidak ada yang peduli pada nasib kita

His character as a provocateur, especially in the civil war on the Mahabharata epic in the kingdom of Hastinapur between Pandava and Kaurava was done for a reason. Sengkuni became evil because he experienced extreme suffering. What happened to Sengkuni is a condition that has never been experienced by anyone else in the history of human life. Sengkuni and his family suffer greatly. The suffering that Sengkuni had experienced became a justification. He only chooses to be a provocateur, not to be a big terrorist, to be a corruptor or act greedy to rule over an empire.

\section{- Consistency of Sengkuni's attitude}

Sengkuni's attitude to stick on the family's decision illustrates that he is someone who is consistent. He still

\section{REFERENCES}

\footnotetext{
Al-Fayyadl, Muhammad (2012), Derrida. Cetakan V. Yogyakarta : LkiS Group

Barry, Peter (2010). Beginning Theory. Cetakan 1. Yogyakarta : Jalasutra
}

escorts his brother Gandari despite various risks. Including the risk of losing all family members. He also continued to carry out the decision of his father - Subolo- Consistency is shown by Sengkuni is a character that is contrary to the character of a hypocrite.

Sengkuni also showed a consistent attitude by did not pretend to be good towards someone. He did not cover up his attitude and identity as done by those of social media users in general.

Saya bukan jenis manusia pengecut, yang sikapnya imbas-imbis, pura-pura baik untuk licik, munafik dan hipokrit, setan pura-pura malaikat, raksasa pura-pura dewa.

Saya bukan manusia cangkem medsos seperti mereka. Saya akan lakukan perang yang sejati dan total. Saya sedang membangun monumen sejarah terbesar sepanjang sejarah"

\section{- Sengkuni is not greedy}

Sengkuni's actions did not motivated by power. He only wanted to protect Gandari and his family. He did not want a bad luck happened to the marriage of his sister as it did not match the neptu count in the calculation of the primbon. He even left the power he had. Excerpts from the drama are as follows:

"Kalau ada yang menuduh bahwa yang saya lakukan ini urusannya adalah nafsu berkuasa untuk melawan penguasa, dengarkan baik-baik: jabatan saya sebagai Raja di utara India, saya tinggalkan. Saya menyingkirkan karena direndahkan dan dihina.

\section{IV.CONCLUSIONS}

The deconstruction put forward by Jacques Derrida has changed the single meaning of a literary work. The meaning of Sengkuni 2019 has inspired our interpretation of the character inherent in Sengkuni. A much different reversal from general knowledge, especially in the Mahabharata epic, was applied to the Sengkuni 2019 manuscript. Provided a new knowledge and understanding of the figure of Sengkuni, deconstruction of many aspects, especially on the character that generates deconstructed meaning.

Sengkuni lives a life full of suffering, the hypocritical nature inherent in him shifts to a consistent nature. Sengkuni still obeyed the family's decision to eat her own family even though it also hurt him. Sengkuni with all the antagonistic characters possessed did not make him wanted to rule, he was not a greedy person.

Derrida, Jasque. 1976, Of Grammatology, Transl. Gayatri C Spivak. Baltimore : The john Hopkins University press

Faruk. 2017. Metode Penelitian Sastra. Cetakan 7. Yogyakarta : Pustaka Pelajar

Haryanto. (1995). Bayang-bayang Adhiluhung (Filsafat, Simbolis, dan Mistik dalam Wayang. Semarang : Dahara Prize 
Juanda, J. 2012. "Bahasa Prokem dan Pembelajaran Bahasa Indonesia" Retorika ; Jurnal Bahasa, Sastra, dan Pembelajarannya, Vol 8 No 1. Retrieved from https://doi.org/10.26858/retorika.v8i1.510

Nurgiantoro, Burhan. 2003. "Wayang dalam Fiksi Indonesia" Humaniora, Vol 15. No 1. Retrieved from https://doi.org/10.22146/jh.769
Ungkang, Marcelus. "Dekonstruksi Jasques Derrida sebagai Strategi Pembacaan Teks Sastra", Vol 1 No 1 Retrieved from http://journal.um.ac.id/index.php/jph/article/view/3919

Utomo, Honggo.(2014). Katalog Festival Dalang Dulongmas III Kabupaten Tegal

Yasasusastra, J. Syahban. 2011. Mengenal Tokoh Pewayangan Biografi, Bentuk dan Perwatakannya. Yogyakarta : Pustaka Mahardika. 